DE GRUYTER GOSPODARKA SUROWCAMI MINERALNYMI - MINERAL RESOURCES MANAGEMENT

\title{
The basic problems of mineral resources valuation methodologies within the framework of System of Integrated Environmental and Economic Accounts
}

\section{Introduction}

Subsoil minerals - e.g. minerals in the strict sense, fossil fuels (coal and hydrocarbons) and industrial rocks - have played a key role in the world's economy over the last century. Their mining is important industry in itself, but it also produces a crucial input into every sector of the economy. In recent years it has been stressed that the fossil fuels has been an important contributor to many environmental problems, and their use is high on the list of concerns about climate change.

The mineral deposit is an unique object of the work that varies with basic financial, economic and technical parameters and, accordingly, with a range of uncertainties. The act of estimating reserve/resource volumes is of great importance and responsibility - that's because all data on a mineral deposit are simultaneously analyzed in detail and, in consequence, conclusions drawn decide of desirability and economic viability of the mining activity and determine the development of the mining projects and their feasibility.

* Professor, The Mineral and Energy Economy Research Institute of the Polish Academy of Sciences, Krakow, Poland; e-mail: krzysztof.galos@min-pan.krakow.pl

** Professor, The Mineral and Energy Economy Research Institute of the Polish Academy of Sciences, Krakow, Poland; e-mail: mark@min-pan.krakow.pl

*** Professor, AGH University of Science and Technology, Krakow, Poland; e-mail: psaluga@zarz.agh.edu.pl **** Ph.D., Andrzej Frycz Modrzewski Krakow University, Krakow, Poland;

e-mail: erobertuberman@poczta.onet.pl 
The values of and changes in the stocks of mineral assets (i.e. changes in mineral resources volumes) are actually in most countries omitted from the national accounts. The current treatment of these resources leads to major anomalies and inaccuracies in the accounts. For example, both exploration and development stages "generate" new mineral assets just as investment creates new produced capital assets. Similarly, the extraction of mineral deposits results in the depletion of mineral assets just as use and time cause depreciation of produced capital assets. The national accounts include the accumulation and depreciation of capital assets, but they do not consider the generation and depletion of mineral ones. The omission is troubling. Mineral resources, like labor, capital, and intermediate goods, are basic inputs in the production of many goods and services. The detection and quantification of mineral resources is not different from the production of consumer goods and capital goods. Therefore, economic accounts that fail to include mineral assets may seriously misrepresent trends in national income and wealth over time. This is particularly evident as production from mineral assets is already included in the nation's gross domestic product (GDP).

Growing awareness of limits set by exhaustibility of natural resources has led to a conclusion that only through their valuation one may assess a comprehensive economic impact of their use. Amongst several others - e.g. forests, fisheries, agricultural lands - mineral resources have been included to almost all studies regarding natural resources assessments.

Valuation of mineral reserves has been a topic of various researches, some of them resulting with adoption of widely recognized valuation methods to their distinctive constrictions, a few resulted with a completely unique prepositions (for a comprehensive review of achievements in this area see: Saługa 2009; Uberman and Uberman 2008). Subsequently they served as a methodological base for various standardization efforts either in field of mineral assets valuation as separate discipline or as a part of broader attempts regulating valuation of assets in general or accounting principles and practices (for a short overview see: Uberman 2014). The resources valuation of undeveloped deposits remains unsolved.

The first attempt of codifying mineral reserves valuation methodology for the purpose of environment related national accounts came in the 1993 edition of the Handbook of National Accounting: Integrated Environmental and Economic Accounting (UN-EC 1993) which was created following requests made by the 1992 United Nations Conference on Environment and Development (Earth Summit) in Rio de Janeiro. One of the key outcomes of these works was a conclusion that measuring value of mineral resources alongside with physical flows of materials, environment related transactions and measuring impact of the economy on the environment should make pillars of this newly designed system, later named as the System of Integrated Environmental and Economic Accounts (SEEA) (UN-EC 2003). SEEA was meant as a framework to compile statistics linking environmental statistics to economic statistics. This means that the definitions, guidelines and practical approaches of the System of National Accounts (SNA) can be applied to the SEEA. One of its aims was to show the economic consequences of not only the extraction of mineral resources but also of their depletion. Simultaneously, a so-called London Group was created in 1993 to allow stakeholders to share their experience in developing and implementing environmental accounts lin- 
ked to the SNA. The London Group is an informal gathering of experts providing them with a forum for review, comparison and discussion of work underway by participants towards development of environmental accounts and become influential stage for methodological discussion on mineral assets valuation. Implementation of SEEA is still in a primary stage and many methodological issues remain unsolved.

The problem of economic evaluation of mineral assets (under SEEA referred to as "subsoil assets") as a part of environment is complex and involves addressing - among others - the below listed challenges:

- The knowledge of deposit is being varied according to the geological assurance of the mode of its occurrence, resource volume, quality, geological and technical accessibility for mining; such knowledge is gained through geological exploration and development and resulted in degree of geological assurance expressed by mineral resource categorization;

- The estimation of geological assurance presents some unsolved problems; it is composed of: confidence to the interpreted geological deposit model (mode and area of occurrence, shape, tectonic features, continuity etc.) and uncertainty of measurable deposit parameters such as thickness, mineral quality, bulk density, etc.; due to natural variation of the value of such parameters their true value distribution and average is known with limited accuracy; such accuracy - if enough data exist - is evaluated by different approaches - most often by geostatistical methods; the confidence of geological model is not exactly measurable; it often depends on knowledge and experience of a geologist presenting it and may be biased by his subjective approach;

- The cost of exploration increases exponentially with assurance gained; it may make deposit value higher due to demonstration of additional resources, but contradictory decrease this value as it itself is a costly activity; the problem presents the reasonable extent of exploration, balancing its cost, deposit value, and risk of imperfect knowledge of demonstrated resources (Nieć 1991; UN-ECE 2003).

\section{Prominent macroeconomic researches regarding mineral resources valuation}

One of the very first efforts to include valuation of mineral resources into national accounts took place in the United States with announcement of the so called "Hotelling's model". Tests of that theory have influenced strongly discussions on the economics of exhaustible resources for many decades. Hotelling (1931) was the first to derive the implications of finite reserves for the evolution of prices and consumption under an optimal plan thus treating mineral resources for the first time as a distinctive subject of macroeconomic research. Hotelling's motivation in writing his then famous paper was twofold. He was reacting to the demand for regulation of the exploitation of exhaustible natural resources by the Conservation Movement, which had been particularly strong in the U.S. during the period from 
1890 to 1920 . But he also wanted to propose an economic theory of exhaustible resources to remedy the inadequacy of what he called the "static-equilibrium type of economic theory" for analyzing an inherently dynamic problem. Hotelling's paper reminded known only in a relative restricted cycle of academics.

The issue of adequacy of natural resources for sustained economic growth became a concern after World War II. This concern gave birth to the President's Materials Policy Commission (Paley Commission), whose report was made public in 1952, and, as an outgrowth, to Resources for the Future, the influential Washington think tank, resulted in publication of report "Scarcity and Growth" (Barnett and Morse 1963), which was the first systematic analysis of long run scarcity measures of a number of natural resources. The big change came in 1970s, with two oil crises and rising prices of almost all natural resources. In academic circles the discussion was somehow initiated by then famous report for to the Club of Rome titled "Limits to Growth" (Meadows et al. 1972), predicting catastrophic consequences for the early twenty-first century unless economic growth was seriously cut back. It was followed by Nordhaus (1973) publishing his very important study entitled "The Allocation of Energy Resources".

From the 1970s on a string of notable papers has been published from which one should indicate efforts, Dasgupta and Heal (1974) as well as Pindyck (1978). Based on methodologies proposed there the Bureau of Economic Analysis (BEA) in the United States and comparable agencies in some other countries have in recent years developed satellite accounts that explicitly identify mineral assets, along with the changes in these assets over time.

Growing interest in natural resources conservation has created a favorable environment for researches regarding their economic value. Special focus has been given to non-renewable resources like land, water, air and landscape. However mineral resources have been given considerably less attention. In this area two issues dominated discussion: oil scarcity and contribution of $\mathrm{CO}_{2}$ resulting from fossil fuel combustion. Such underweighting is groundless. Exploitation of mineral resources has supported civilization growth over centuries and they have to be valued on equal basis to other natural resources. Thus methodological efforts have to be continued at accelerated pace.

\section{Mineral resources valuation within the first SEEA attempts}

Mining industry is the significant segment of the nation's output, though the extraction of subsoil minerals is commonly linked to many serious environmental problems. Moreover, while the value of mineral assets may be a small fraction of the nation's total assets, mineral assets can account for a large proportion of the assets of certain regions of the country.

The explored mineral deposits have known and limited territorial extent and fixed location in space. Mining requires then exclusion of sometimes vast and valuable land plots; it often provokes conflict of varied possible modes of a given territory utilization. Mineral deposits are visualized in land use planning. However, violent opposition against develop- 
ment of deposit is often present. Such opposition is motivated often by economic value of ground over the deposit area, e.g. for long term agricultural utilization, residential, industrial or commercial plant building (Nieć and Radwanek-Bąk 2009). Lack of widely recognized methodology for valuation of mineral assets forms a significant obstacle in objective parameterization of uses in consideration and therefore leads to a waste of significant national wealth through leaving idle valuable assets.

In numerous countries, at least some mineral deposits are the property of the State Treasury. Therefore they have to be considered as a part of a common property of Nation. Their exploration and development should be considered as the source of national wealth through generating labor sites, state monetary income and general economic development of the country (Bohdanowicz 1927; Galos 2013). As such, known mineral deposits have economic value which should be evaluated.

The prevailing treatment of mineral assets in the national economic accounts has three major limitations. First, there is no entry for additions to the stock of mineral assets under production or asset accounts. This omission is anomalous because businesses expend significant amounts of financial resources on discovering or proving resources for future use. Second, there is no entry for the depletion of the stock of mineral assets under production accounts or asset accounts. When the stock of a valuable resource declines over time through intensive extraction, this trend should be recognized in the economic accounts: if it is becoming increasingly expensive to extract the minerals necessary for profitable output, the nation's sustainable production will be lowered. Third, there is no entry for the contribution of mineral assets to current exploitation in the production accounts. Their contribution is currently recorded as a return to other assets, primarily as a return to capital (BEA 2000).

The major difficulty for the national accounts has been very limited availability of data on transaction prices of mineral resources. Unlike man made capital goods such as houses or cars, additions to mineral resources and/or reserves are not generally reflected in market transactions, but are determined from internal and often proprietary data on mineral assets. Moreover, there are insufficient data on the transactions of mineral resources, and because these resources are quite heterogeneous, extrapolating from existing transactions to the universe of resources and/or reserves is questionable (BEA 2000).

The growing worldwide awareness of inter-linkage between environmental issues and economic development caused that United Nations Environment Program (UNEP) requested in 1982 that methodological guidelines for developing countries on environmental accounting were created to be applied for development planning and policy. A series of five workshops was subsequently held with results summarized seven years later in form of a World Bank publication, where it was clearly stated that accounting had to recognize misleading of so called "free lunch" approach to use of natural resources and "learn to distinguish between true income generation and drawing down of capital assets by resources depletion or degradation" (Ahmad et al. 1989). Consequently, United Nations Conference on Environment and Development (Earth Summit) in Rio de Janeiro in 1992 passed the Resolution 1, which in Annex II, par. 40.6 and 40.7 requested preparation of comprehensive 
indicators reflecting contribution of use of natural resources to GDP formation. As a result of this resolution, based on previous researches, the first edition of the "Handbook of national accounting: Integrated environmental and economic accounting" (UN-EC 1993) turned out. As it was indicated above the handbook pioneered the notion of System of integrated Environmental and Economic Accounts (SEEA) which then became a widely recognized expression describing part of national accounts devoted to natural resources. From the very beginning mineral assets, defined under the notion of subsoil assets, were considered within its framework.

The handbook was subsequently supplemented by publication of an operational manual in 2000 as well as by its new editions in 2003 (UN-EC 2003) and 2012 (UN-EC 2014), then with cooperation of the World Bank, IMF, OECD and European Commission. The last 2014 edition represents certain change of approach. Instead of one comprehensive handbook it offers fundaments (SEEA Central Framework) to be complemented by specific publications on selected areas. It is also planned that the SEEA Central Framework will be supported by related publications which further elaborate the conceptual framework of the SEEA for specific sectors, including, for example, the SEEA-Water and the SEEA-Energy. These specific publications may also be supported by international recommendations that provide guidance on data items, data sources and methods for developing the basic statistics that can be used, among others, to populate the accounting tables.

Simultaneously, as it was indicated above, the London Group was created in 1993. The name was derived from the place of its first meeting in March 1994. The London Group is an informal gathering of experts, primarily from national statistical agencies but also international organizations. It's meetings provide a forum for review, comparison and discussion of work underway by participants towards development of environmental accounts and become influential stage for methodological discussion on mineral assets valuation. The group has held 20 plenary meetings (Uberman 2014), the last in October 2014.

Another development in the international environmental-economic accounting was the creation of the United Nations Committee of Experts on Environmental-Economic Accounting (UNCEEA) in March 2005 in order to elevate the System of integrated Environmental and Economic Accounting (SEEA 2003) to a globally recognized international statistical standard what could be achieved only via advancements in swift methodological fields. The London Group was requested of the UNCEEA to participate as a key player in research agenda for the revision of the SEEA-2003 as part of its work program. Until now, this body held 9 plenary meetings (Uberman 2014).

It has to be considered as undesirable that Poland has not been represented in any significant activities of the above indicated bodies. The only document coming from our country on the issue was the Environmental Protection Expenditure Account in Poland. Report on the Pilot Project (Broniewicz 2005), which was a review of data available to the Central Statistical Office and did not refer to valuation of mineral resources at all. 


\section{Hitherto methodological works and achievements published within the SEEA development framework}

Natural resources are to be included into the accounts to make it possible to describe stocks and changes in stocks in monetary terms. Therefore issue of the valuation of this natural capital, the physical quantities and qualitative aspects that tend not to have market monetary value, yet, becomes essential. Facing this challenge, in course of work on SEEA several key issues regarding valuation of mineral deposits had been identified and addressed (Uberman 2014):

- inclusion or exclusion certain items from the scope;

- relation between exploration expenses and value of mineral resources/reserves;

- relation between developed mineral reserves and associated investment in fixed assets;

- recognition of decommissioning extractive structures as well as recovery of land.

Issue of scope has two dimensions. The first one refers to minerals flows recognized in national statistics. Generally countries tend to report flows of hydrocarbons, coal and metallic raw materials, although even in these cases important differences occur. Secondly the discussion relates to geological systematics of mineral assets. Unfortunately, as already indicated above, despite numerous efforts (Nieć 2010), no universally recognized system regarding classification of mineral deposits has been developed yet (for further discussion of this issue see point 4).

The special cases of valuation of mineral assets refer to the relationship between exploration costs and valuation of new discoveries "in situ". In commercial accounts these exploration expenditures are usually treated as a form of capital formation and recognized in form of "capitalized expenses". In recognition of the fact that the benefits of exploration efforts are usually substantially delayed, SNA - from 1993 - introduced mineral exploration as a new, separate category of intangible fixed capital. Expenditures in consideration shall include pre-license costs, license and acquisition costs, appraisal costs and the costs of actual test drilling as well as the costs of aerial and other surveys, transportation costs, etc., incurred to make it possible to carry out the tests. Such solution posts a danger of double counting. Should a market exist in parallel for geological information and deposits themselves, the market price would be possible to get identified easily. Regretfully such situation rarely occurs. Therefore special methods had to be adopted to assure both credible appropriation of value between exploration and deposits per se (Uberman 2014).

Mineral exploration costs question relates to another one that often has to be solved within the framework of national accounts - the ownership issue. In many cases an ultimate title to natural resources belongs to a state regardless specific arrangements enabling various entities to perform activities like exploration, development, extraction. Leaving apart the issue of mineral exploration assets presented above and assuming that a given mineral de- 
posit has entered any further stage of development, SEEA offers two options with the choice depending primary on terms of relevant agreement (UN-EC 2003; Uberman 2014):

- in case they give to the extractor the right to retain some of the resource rent of the asset, it considers as appropriate to record the value of the mineral deposit as a sum of values belonging to the owner and the extractor according to the proportions each is expected to receive;

- in case the extractor in effect obtains ownership rights by ceasing all important decisions, especially about extraction times and volumes in return for a financial consideration then the owner will disclose a financial claim instead of the deposit while the extractor will recognize the deposit as an asset but also will be obliged to record the financial liability offsetting it.

Valuation of mineral resources is often additionally complicated as a recording of associated investment in produced assets has to occur simultaneously. From a purely theoretical point of view value of fixed assets employed in extracting activities shall be differentiated from the value of deposits themselves (Uberman 2014). SEEA seems to fully support this preposition focusing instead on practical calculation problems. Admitting extreme difficulties in using market or cost based approaches it gives in depth consideration to recognition of this issue in income based approach (UN-EC 2003).

Giving aims and scope of SEEA an understandably extensive deliberation is given to the problem of decommissioning of mines and well rigs. It recognizes that in case of mining and exploration sites most of environmental protection costs are actually incurred at the end of their useful life. It points out that the major difficulty here is derived from the fact that as oppose to disposals of majority of other assets in the case of mining decommissioning costs are incurred at the end or after the life of the owning enterprise when there is no income against which to set these costs. They must not be neglected though. It is clearly stated that at the end of a produced asset's life, the residual value in the balance sheet should be exactly zero. Consequently residual items must no longer present any risk of damage in future and land used in extraction should have been reclaimed. The value of the terminal costs represents the cost of improving components of environment to their desired states (Uberman 2014).

Despite noticeable achievements resulting from works framed by SEEA at present there is no one generally accepted methodology of economic evaluation of undeveloped deposits which may be mined in not determined future. The problem is even more complex in the case of undiscovered but suspected deposits in prospective areas which should also be protected against such land use which may preclude their future development. A helpful tool may be here real options analysis (ROA), that delivers means enabling valuation of delay and flexibility (Saługa 2011).

In addition to the above presented developments some independent works partially related to valuation of mineral deposits for environmental valuation has been published (e.g. Rietbergen-McCracken and Abaza 2013; Sinclair and Blackwell 2004). However, none of such research works demonstrated a comprehensive evaluation of available methods with clear recommendations as to principles and methods to be used in linking this area of 
environmental accounts into the System of National Accounts, taking into account peculiar character of such a methodology, distinct from methodologies applied for other purposes.

Dissemination of SEEA still remains limited. It was admitted in 2003 that very few countries had developed a broad range of accounts, and no country has yet developed the full set of such accounts. Surprisingly, there is also a very limited number of presentations regarding implementation of SEEA in particular countries. However one can indicate Norway, Canada, Australia, the Netherlands and several others as clearly committed to this task (UN-EC 2014).

Research on environmental accounting treating mineral resources value as part of national accounts has not been practically carried out in Poland what may come as surprise giving number of publications discussing related topics like for example measuring influence of environment on various aspects of human lives. However they tend to concentrate on pollution, forests and environment damaging. They often attempt to apply predefined methodologies in order to establish a value of damage caused by human activities in selected cases. A few books published covering the issue of natural resources valuation discuss mostly on foreign methodologies (Szyszko et al. 2013; Fiedor 2002).

As importance of mineral resources for further Polish economic development cannot be questioned, especially as Poland is one of the most gifted European countries and still maintains an active mining sector (Smakowski et al. 2014), the above presented issues are relevant for our country, too. The monetary assessment of resources available, extracted and depleted becomes a necessity if any meaningful policy of sustainable growth is to be implemented. The physical flow of mineral raw materials in Poland and value of mineral production is reported annually in Minerals Yearbook of Poland (Smakowski et al. 2014), while reporting on quantitative information of mineral resources and reserves in Poland by the Polish Geological Institute (Szuflicki et al. 2014). However, monetary information there is limited to the value of produced mineral commodities (reported in Minerals Yearbook of Poland on the basis of data from the Central Statistical Office). There is a lack of works on valuation of mineral resources in Poland. Some single valuations of mineral reserves are only occasionally prepared for privately owned entities or due to a public listing of mining companies. Until now there is also a lack of any approach of SEEA to be a part of National Accounts.

\section{Resource/reserve classification systems as a basis of introduction of mineral resources valuation}

The fundamental obstacle faced by scientists and practitioners researching the issue in mineral resources valuation comes from a worldwide variety of mineral deposits geological classifications and thus their reporting systems. Regulation of the reporting of reserves and resources of mineral properties has been increasing substantially in the last decades and is constantly evolving. In 1989 the Joint Ore Reserves Committee of the Australasian Insti- 
tute of Mining and Metallurgy (AusIMM), the Australian Institute of Geoscientists (AIG), and Minerals Council of Australia introduced a strict code for estimating resources and reserves - the Australasian Code for Reporting of Exploration Results, Mineral Resources and Ore Reserves, commonly called the JORC Code (Saługa 2009). The JORC Code has rigorous enforcement provisions and has been incorporated in its entirety into the listing rules of the Australian Stock Exchange. Since the date of publication one can observe growing international acceptance of it - the Code has become an informal international standard and many countries have been studying it in order to improve their corporate governance regime and assure adequate public revealing in the assessment of mineral assets/properties. JORC-type regulations are embodied in the similar codes, guidelines and standards published and adopted by the relevant professional bodies in other countries (Njowa et al. 2014).

In 1994 the Committee for Mineral Reserves International Reporting Standards (called CRIRSCO) was founded. It has gained recognition by some global organizations such as the International Accounting Standards Board (IASB), the United Nations Economic Commission for Europe (UNECE) and the International Council on Mining and Metals (ICMM), as the key international organization representing the mining industry on issues relating to the classification and reporting of mineral assets. The current members represent Australia, Canada, Chile, South Africa, the European Union, Russian Federation and the USA. CRIRSCO is open for other regions and countries. The CRIRSCO uses an own template derived from Australasian code. It is a set of standard definitions and principles which are incorporated in a group of standards ('codes') developed nationally by the affiliated reporting organisations: the mentioned JORC (Australia 1989 - last 2012), CIM Standards (Canada 2000), SAMREC (South Africa 2000), PERC (Europe 2001), SME Guide (United States 1992), Certification Code (Chile 2004) and NAEN (Russia 2011); some of the most important parts that constitute for in the CRIRSCO template are definitions of 'resources' and 'reserves' (Njowa et al. 2014).

Then, since the introduction of the JORC Code, considerable progress has been made towards widespread adoption of consistent reporting standards throughout the world. Further developments in resource/reserve reporting issues is underway.

For hydrocarbons Petroleum Resources Management System (PRMS) was proposed and accepted as standard in international relations (Ross 2011). It was harmonized with CRIRSCO template through UNFC resources classification.

The both: CRIRSCO (Jorc Code) and PRMS divide resources and reserves into several categories but in different ways. CRIRSCO resources and reserves classification is based on degree of geological assurance and the knowledge of economic, technical, social and political modifying factors transforming resources into reserves as recoverable quantities. PRMS defines resources as quantities demonstrated as potentially recoverable but not involved in production process and reserves as quantities prepared for production or engaged in it. The low, best and high estimates of resources are presented depending on probability of their real occurrence. 
In Poland, strictly observed code of reporting mineral resources exist since year 1952, updated in 1962, 1980, 1994 and 2001. It is valid for resources evaluation only. The resources/reserves volumes - depending on reliability and accuracy of geological data - are classified in Poland into five categories: A, B, $\mathrm{C}_{1}, \mathrm{C}_{2}$ and D, and according to technical recoverability as well as supposed economic value are divided into "balance" (supposed technically and economically mineable) and "out of balance" (subeconomic). The distinction of resources and reserves as presented in JORC Code was not formally defined. In the Polish classification system the "industrial reserve base" ("zasoby przemysłowe") and predicted recoverable reserves - "operational" ("zasoby operatywne") are distinguished within the balance resources. The so-called "industrial reserve base" consists of a part of resources that are considered as suitable for mining through defined technology and in predictable economic conditions. The predicted recoverable reserves are most often calculated as product of industrial reserve base and expected recovery coefficient, supposed according to former mining experience and data (so they are resources designed for mining diminished by mining losses). The both "reserve base" and predicted recoverable reserves are presented in the "mine development plan", that has the features of prefeasibility study.

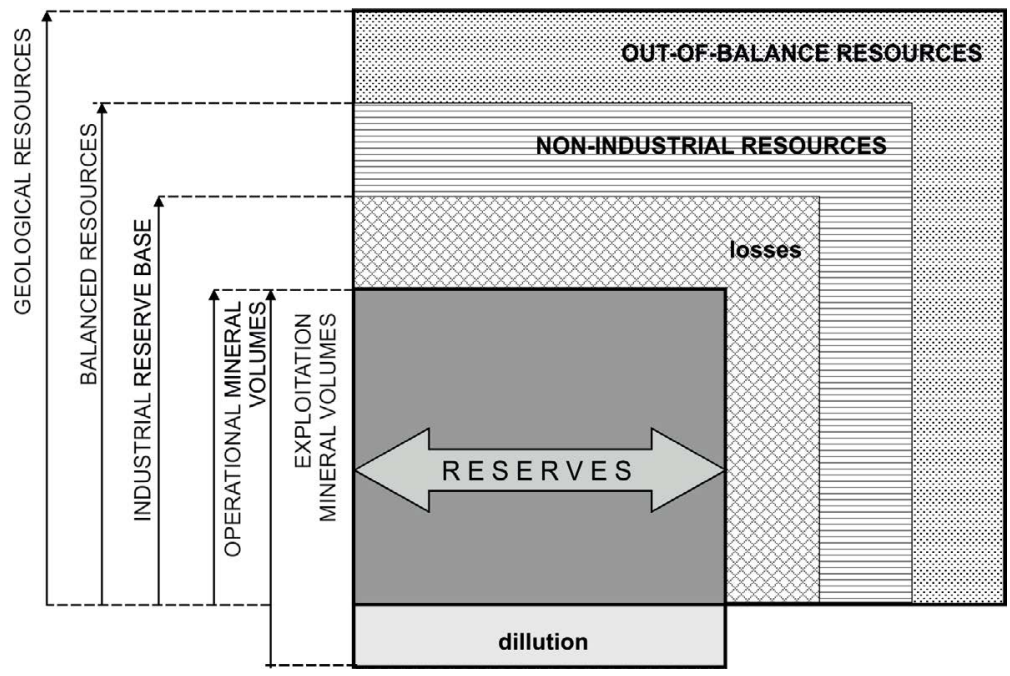

Fig. 1. Polish resource classification system (Saługa 2011)

Rys. 1. Polski system klasyfikacji zasobów (Saługa 2011)

The Polish classification system can be compared with other ones through UNFC. However it is not so easy to harmonize it with the JORC Code - CRIRSCO template (Nieć 2010) due to different used terminology as it was presented above.

Lack of understanding of Polish code of resources reporting system lead into misunderstanding or misinterpretation of mineral volume statements made in Poland, by foreign accountants, appraisers and investors. That's why Polish mineral volume estimates are not 
acceptable on major international capital markets. Therefore elaboration of guidelines for transferring Polish mineral volume categorization into international CRIRSCO resource/ reserve reporting standard and "resources" and "reserves" classes is necessary. Such guidelines should be designed for use in international markets and public disclosures.

\section{Conclusions - the problems of mineral resources valuation}

In numerous countries, Poland including, mineral deposits create a significant portion of their respective national wealth. Their development should be considered as the source of national wealth through generating labor sites, state monetary income and general economic country activization. As such, known mineral deposits have economic value which should be evaluated.

Mineral assets are only quantitatively and qualitatively estimated in National Accounts, as a potential source of mineral raw materials, that can be used in the future. Valuation methodology is elaborated for reserves of developed or prepared for development only. However it meets difficulties due to indicated differences in resources/reserves categorization systems.

These problems are extremely visible in case of resources valuation of undeveloped deposits. The explored mineral deposits have known and limited territorial extent and fixed location in space. It provokes conflict of various possible modes of this territory utilization. It is visualized in land use planning and presented in violent opposition against mineral deposits development. Such opposition is motivated often by economic value of ground over the territory of deposit occurrence e.g. for long term agricultural utilization, residential, industrial or commercial plant construction.

At present there is no one accepted general methodology of economic valuation of mineral assets which may be mined in not determined future. The problem is still more composed in the case of undiscovered but suspected deposits in prospective areas which should be protected against such land use which may preclude their exploration and future development. The analyses performed identified that the challenge of creating such methodology should be decomposed into two tasks:

- creation of an universally accepted geological resources classification,

- development of a set of valuation methodologies strictly linked to such classification.

The special issue is limited confidence to resources estimation and accuracy of data. Moreover, if development of mineral resources is not planned in predictable future, estimation of their value is additionally complicated. The problem of economic evaluation of undeveloped deposits is composed and several questions should be answered.

The knowledge of deposit is varied according to the geological assurance of deposit resources, as well as its geological and technical accessibility for mining. The estimation of geological assurance of reported resources volume presents some unsolved problems. It is composed of: confidence to the interpreted geological deposit model (mode and area of 
occurrence, shape, tectonic features, continuity etc.) and uncertainty (accuracy of estimation i.e. possible error) of measurable deposit parameters such as thickness, mineral quality, bulk density. Due to natural variation of such parameters value, their true distribution and average is known with limited accuracy. Such accuracy is evaluated by different approaches, most often, if exist enough data, by geostatistical methods. The confidence of geological model is not exactly measurable. It often depends of knowledge, experience of geologist presenting it and may be biased by his subjective approach (and sometimes unreasonable fantasy).

At present there is a lack of generally accepted methodology for assessment of geological assurance of resources. The proposed internationally accepted resources classification systems as e.g. JORC Code, UNFC, define the degree of assurance (and various resources classes respectively) in descriptive mode, without clear comparable criteria. The PRMS classification of hydrocarbon resources divide them into classes according to their probability, however it lacks criteria for estimation of geological assurance.

The above indicated gap posts almost unsolvable challenge to a development of valuation methodologies per se. Since the object of valuation is not universally categorized, efforts to create meaningful valuation rules will always lead either to set only some very general standards or an almost infinite set of particular variations reflecting differences in geological classification

Poland, as a quite resourceful country, thus gifted with a significant natural endowment, has a special interest in development methodologies leading to set policies assuring its effective usage. Thus entities responsible for scientific research shall consider themselves responsible and demonstrate a clear interest in their development.

\section{REFERENCES}

Ahmad et al. 1989 - Ahmad, Y., Serafy, S.E., Lutz, E. eds. 1989. Environmental Accounting for Sustainable Development. Washington D.C.: World Bank, $100 \mathrm{pp}$.

BEA 2000 - Accounting for Subsoil Mineral Resources. From the February 2000 Survey Of Current Business. Washington D.C.: Bureau of Economic Analysis, US Department of Commerce.

Barnett, H.J. and Morse, Ch. 1963. Scarcity and Growth: The Economics of Natural Resource Availability. Baltimore: The John Hopkins Press, 288 pp.

Bohdanowicz, K. 1927. Zasoby mineralnych surowców w Polsce $i$ wynikajace z zależności od nich zagadnienia narodowej gospodarki. Dąbrowa Górnicza: Druk. E. Mirek i s-ka. (in Polish).

Broniewicz, E. ed. 2005. Environmental Protection Expenditure Account in Poland. Report on the Pilot Project. Warszawa-Białystok: Wyd. Ekonomia i Środowisko, 56 pp.

Dasgupta, P. and Heal, G. 1974. The Optimal Depletion of Exhaustible Resources. The Review of Economic Studies 41, pp. 3-28.

Fiedor, B. ed. 2002. Podstawy ekonomii środowiska i zasobów naturalnych. Warszawa: C.H. Beck, 484 pp. (in Polish)

Galos, K. 2013. Strategie surowcowe wybranych krajów Unii Europejskiej. Zesz. Nauk. IGSMiE PAN 85, pp. 29-45 (in Polish)

Hotelling, H. 1931. The Economics of Exhaustible Resources. Journal of Political Economy 39, 2, pp. 137-175.

Meadows et al. 1972 - Meadows, D.H., Meadows, D.L., Randers, J. and Behrens, W.W. 1972. The Limits to Growth: A Report for the Club of Rome's Project on the Predicament of Mankind. New York: Universe Books, 210 pp. 
Nieć, M. 1991. Geologia kopalniana. Warszawa: Wyd. Geol., 504 pp. (in Polish).

Nieć, M., 2010. Międzynarodowe klasyfikacje zasobów złóż kopalin. Górnictwo i Geoinżynieria. Kwartalnik AGH 34, 3, pp. 33-49 (in Polish).

Nieć, M. and Radwanek-Bąk, B. 2009. Wykorzystanie złóż kopalin w Polsce a zagrożenia bezpieczeństwa surowcowego kraju. Przegląd Geologiczny 57, 7, pp. 591-599 (in Polish).

Njowa et al. 2014 - Njowa, G., Clay, A.N. and Musingwini, C. 2014. A perspective on global harmonisation of major national mineral asset valuation codes. Resources Policy 39, pp. 1-14.

Nordhaus, W.D. 1973. The Allocation of Energy Resources. Brookings Papers on Economic Activity 3, pp. 529-570.

Pindyck, R.S. 1978. The optimal exploration and production of nonrenewable resources. Journal of Political Economy 86 , pp. 841-61.

Rietbergen-McCracken, J. and Abaza, H. eds. 2000. Environmental Valuation. A Worldwide Compendium of Case Studies. Abington: Earthscan, 256 pp.

Ross, J. 2011. Petroleum resources definitions, classification, and categorization guidelines. [In:] Guidelines for Application of the Petroleum Resources Management System, pp. 7-22.

Sinclair, A.J. and Blackwell, G.H. 2004. Applied Mineral Inventory Estimation. Cambridge: Cambridge University Press, $400 \mathrm{pp}$.

Saługa, P. 2009. Ocena ekonomiczna projektów i analiza ryzyka w górnictwie. Studia, Rozprawy, Monografie nr 152 Kraków: Wyd. IGSMiE PAN, 278 pp. (in Polish).

Saługa, P. 2011. Elastyczność decyzyjna w procesach wyceny projektów geologiczno-górniczych. Studia, Rozprawy, Monografie nr 167. Kraków: Wyd. IGSMiE PAN, 269 pp. (in Polish).

Smakowski i in. 2014 - Smakowski, T., Galos, K. and Lewicka, E. eds. 2014. Minerals Yearbook of Poland 2013 Warszawa: Wyd. PIG-PIB, 567 pp.

Sobczyk, E.J. and Saługa, P.W. 2013. Coal Resource Base in Poland from the Perspective of Using the JORC Code. [In:] Proceedings of the 23rd World Mining Congress, CIM Journal, Canada.

Szuflicki et al. 2014 - Szuflicki, M., Malon, A. and Tymiński, M. 2014. Bilans Zasobów Złóż Kopalin w Polsce wg stanu na 31.12.2013 r. Warszawa: Wyd. PIG-PIB, 466 pp. (in Polish).

Szyszko et al. 2013 - Szyszko, J., Rylke, J., Jeżewski, P. and Dymitryszyn, I. 2013. Ocena i wycena zasobów przyrodniczych. Warszawa: Wyd. SGGW, 460 pp. (in Polish).

Uberman, R. and Uberman, R., 2008. Podstawy wyceny wartości złóż kopalin. Teoria i praktyka. Kraków: Wyd. IGSMiE PAN, 151 pp. (in Polish).

Uberman, R. 2014. Valuation of Mineral Resources in Selected Financial and Accounting Systems. Natural Resources $9 / 5$, pp. $496-506$

UN-EC 1993 - United Nations, European Commission, 1993. Handbook of national accounting: Integrated environmental and economic accounting, Interim version. United Nations: Studies in Methods, Series F, No. 61, New York.

UN-EC 2003 - United Nations, European Commission, 2003 - Handbook of national accounting: Integrated environmental and economic accounting. International Monetary Fund, Organisation for Economic Cooperation and Development \& The World Bank: Studies in Methods, Series F, No. 16, New York.

UN-EC 2014 - United Nations, European Commission, 2014 - System of Environmental Economic Accounting. Central Framework., International Monetary Fund, Organisation for Economic Cooperation and Development \& The World Bank. Studies in Methods, Series F, No. 16, New York.

UN-ECE, 2013 - United Nations Economic Commission for Europe, 2013 - United Nations Framework Classification for Fossil Energy and Mineral Reserves and Resources, incorporating specifications for its application. ECE Energy series no. 42, N. York, Geneva. 


\section{PODSTAWOWE PROBLEMY METODOLOGII WYCENY ZASOBÓW MINERALNYCH W RAMACH SYSTEMU ZINTEGROWANYCH ŚRODOWISKOWYCH I EKONOMICZNYCH RACHUNKÓW NARODOWYCH}

Słowa kluczowe

zasoby kopalin, wycena złóż kopalin, rachunkowość środowiskowa, rachunki narodowe

\section{Streszczenie}

Rosnąca świadomość ograniczeń wynikających z faktu wyczerpywalności niektórych zasobów naturalnych spowodowała, że potrzeba monetarnej wyceny ich wartości jako sposobu odzwierciedlenia ekonomicznego wpływu ich użytkowania stała się bardzo istotna. Zasoby kopalin były od samego początku uwzględniane w prawie wszystkich studiach dotyczących wyceny zasobów naturalnych. Pierwszym, szeroko uznanym efektem tych prac było opublikowanie 1993 roku podręcznika „Handbook of National Accounting: Integrated Environmental and Economic Accounting”. Jednym z głównych rezultatów tych prac była konkluzja, że podstawowe znaczenie dla planowanego Systemu Zintegrowanych Środowiskowych i Ekonomicznych Rachunków Narodowych (skrót ang. SEEA) ma określenie wartości kopalin użytkowanych do produkcji surowców mineralnych, wraz z rejestracją ich przepływów fizycznych oraz związanych z tym transakcji, z uwzględnieniem wpływu związanej z tym działalności gospodarczej na środowisko. Wdrożenie SEEA znajduje się wciąż w fazie początkowej, a wiele problemów metodologicznych nie zostało rozwiązanych. Niniejszy artykuł dokonuje inwentaryzacji dotychczasowych osiągnięć oraz wskazuje kierunki dalszych niezbędnych prac w tym obszarze.

Wobec dużego znaczenia właściwego wykorzystania zasobów kopalin znajdujących się na terytorium Polski dla rozwoju gospodarczego naszego kraju autorzy wskazują na konieczność rozwoju i wdrożenia odpowiedniej metodologii, która mogłaby pozwolić na monetarne określenie wartości dostępnych zasobów kopalin, z uwzględnieniem wartości wydobytych kopalin trafiających do obiegu gospodarczego, co ma stanowić jeden z ważnych fundamentów polityki zrównoważonego rozwoju gospodarczego. Szczególnym problemem jest ocena wartości rozpoznanych, ale jeszcze niezagospodarowanych złóż kopalin. 
THE BASIC PROBLEMS OF MINERAL RESOURCES VALUATION METHODOLOGIES WITHIN THE FRAMEWORK OF SYSTEM OF INTEGRATED ENVIRONMENTAL AND ECONOMIC ACCOUNTS

\author{
Keywords
}

mineral resources, mineral asset valuation, environmental accounting, national accounts

Abstract

Growing awareness of limits set by exhaustibility of natural resources has led to a conclusion that only through their valuation in monetary terms one may assess a comprehensive economic impact of their use. Thus mineral resources have been included from the beginning to almost all studies regarding natural resources assessments. The first result, widely recognized by international community, of researches came in the 1993 - edition of the "Handbook of National Accounting: Integrated Environmental and Economic Accounting". One of the key outcomes of these works was a conclusion that measuring value of mineral resources for mineral raw materials production, alongside with physical flows of these materials, environment related transactions and measuring impact of the economy on the environment, should make basic pillars of this newly designed system, later named as the System of Integrated Environmental and Economic Accounts (SEEA). As implementation of SEEA is still in a primary stage, many methodological issues remain unsolved. This article attempts to enumerate achievements made so far and indicate issues in need for further development.

Taking into account the importance of mineral resources for further economic development of Poland authors indicate a necessity to develop and implement methodologies for monetary assessment of resources/reserves available, extracted and depleted in order to form a methodological base for a meaningful policy of sustainable growth. The special challenge results from monetary assessment of explored but yet undeveloped mineral deposits. 